International Conference on Business Research

University of Moratuwa, Moratuwa, Sri Lanka

June 13, 2018, 29-38.

DOI: https://doi.org/10.31705/ICBR.2018.5

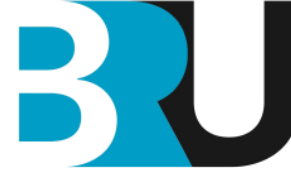

BUSINESS RESEARCH UNIT

FACULTY OF BUSINESS

UNIVERSITY OF MORATUWA

\title{
Design thinking for business and entrepreneurship: accelerating innovation in higher education in Sri Lanka
}

\author{
Gnanaharsha Beligatamulla*
}

Department of Integrated Design, Faculty of Architecture, University of Moratuwa, Sri Lanka, and

School of Design, Creative Industries Faculty, Queensland University of Technology, Australia

\begin{abstract}
"Design thinking" is a popular concept in today's business and in many transdisciplinary educational settings which are focussed on innovation. Globally, many universities facilitate design thinking for students both in design and non-design contexts. This concept paper put forward the possibility of using design thinking as a catalyst to support innovation in higher education: particularly in the context of business and multi-disciplinary educational settings in Sri Lanka. Sri Lankan universities have lack of engagement with facilitating design thinking for students. However, there are few public universities obsessed with innovation, entrepreneurship and business design in Sri Lanka. This article reviews extant literature relevant to design thinking in higher education context while providing a few examples of design thinking courses. Then the paper discusses the current state of the design, innovation and entrepreneurial education in public universities across Sri Lanka by selecting a few Masters of Business Administration (MBA) courses. Finally, the evidence of the study highlights that there are possibilities of facilitating design thinking in Sri Lankan higher education.
\end{abstract}

Key words: design thinking, business innovation, entrepreneurship, creative problem-solving, higher education

\section{Introduction}

Design thinking refers to methods or strategies that traditionally designers use during the process of designing (Cross, 2006; Dorst, 2011; Dym, Agogino, Eris, Frey \& Leifer, 2005; Lawson, 2006). Despite it being a core aspect of designing, different people interpret and use design thinking in different ways: such as identifying it as a general methodology of design, a mind-set, a

*Email: designergnanaharsha@gmail.com 
creative problem-solving process, a toolkit for innovation (Brown, 2009; Johansson-Sköldberg, Woodilla \& Çetinkaya, 2013; Kimbell, 2011). This is becoming more apparent today where it is increasingly applied in non-design professions for dealing with complex problems (Liedtka, Salzman, \& Azer, 2017a).

The connection between design and business is quite usual (Muratovski, 2016) mainly in the traditional sense where the objective of designing is a tangible outcome such as in industrial design and fashion design. Design is used to innovate projects inside a business (Muratovski, 2016). However, in the first decade of $21^{\text {st }}$-century design and design thinking have also been recognised as a method to run a business and for business management where managing is viewed as designing (Boland \& Collopy, 2004). Hence, today, design thinking is widespread as a strategic approach to business design and innovation (Holloway, 2009; Vianna, Vianna, Adler, Lucena \& Russo, 2012) as well as in business analysis (Frisendal, 2012).

Brown $^{1}$ (2008, 2009) provides several exemplary projects for design thinking from IDEO: all drawn from the broad world of business and innovation as opposed to traditional design, engineering or technology. "Venture capitalist firms and start-ups increasingly recognise the value of including designers in the early stages of business development" (Muratovski, 2016, p. 21). Further, Liedtka, Salzman, and Azer (2017b) provide abundant examples of how social sector organisations in areas such as healthcare, education, the arts, the environment, government policy, transportation, and social services use design thinking to utilise what they do and better serve society. Herein design thinking is being considered as a service design process and a problem-solving process reflecting a human-centred understanding of and approach to design.

Increasing interest in research and practice regarding problem-solving, creativity and innovation and its perceived contribution to economic growth and social benefit has contributed to the emergence of design thinking as a widespread phenomenon in education, including the higher education context (Goldman \& Kabayadondo, 2017; Koh, Chai, Wong, \& Hong, 2015; Matthews \& Wrigley, 2017). In addition to the various design disciplines, design thinking is now being practised, facilitated and taught in disciplines as diverse as engineering, business, management, information technology, and education.

However, in Sri Lanka (SL) there are no dedicated courses for design thinking in government universities. Some design-based degree courses have embedded design thinking in their modules in the University of Moratuwa, Sri Lanka. Although there is a lack of facilitation of design thinking in collaborative and transdisciplinary educational settings in Sri Lanka, there are innovations which happen in unique educational settings (Asian Development Bank, 2016). Most of these innovations are in isolation from business and

\footnotetext{
${ }^{1}$ Although there are several books and papers on the wide application of design thinking in business organisations, Change by Design: How Design Thinking Transforms Organizations and inspires innovation by Tim Brown (2009) is the most cited book for design thinking. He is the CEO of IDEO which is recognized as the most celebrated innovation and design firm in the world.
} 
commercialisation with a lack of entrepreneurial spirit among academics and a low commercialisation potential (Larsen, Bandara, Esham, \& Unantenne, 2016). Being ranked $94^{\text {th }}$ place (Score 29.1 in a 0-100 scale) in the Global Innovation Index Rankings (Dutta, 2012, p. 9), Sri Lanka has a potential to cultivate the innovation culture. Design thinking has proven to be a better option to bridge the gaps while bringing a multidisciplinary nature in education (Ramanantsoa, 2015).

Hence, this concept paper promotes design thinking education among Sri Lankan higher education institutions for cultivating and fostering innovation skills and creative problem-solving capacities. The paper, first, provides a literature review from global higher educational context. Subsequently, the discussion is on the current state of the design, innovation and entrepreneurial education in public universities across SL. Finally, the discussion is on the possibilities of facilitating design thinking in Sri Lankan higher education.

\section{Method}

As mentioned before, this concept paper does not employ any empirical data gathering from Sri Lankan context. It solely relies on the literature available and a desk study. It is acknowledged that some of the ideas are influenced by the author's previous engagement in design thinking teaching in Sri Lankan higher education context. The first online desk study was conducted to understand the current nature of business design, innovation and entrepreneurial education in Sri Lanka. A specific search through the academic peer-reviewed journals was conducted to identify the current scholarly publications around design thinking in Sri Lankan higher education: but there were no such publications found. However, few university courses which had a related curriculum (content of teaching) with business, innovation and entrepreneurship were found through browsing each university web pages and course guides. Several MBA courses and their providers were closely perused to understand the current nature of teaching business, design, entrepreneurship and innovation in SL. These institutions include Faculty of Commerce and Management Studies, University of Kelaniya; Faculty of Management and Finance, University of Colombo; Postgraduate Institute of Management (PIM), University of Sri Jayewardenepura; Postgraduate Institute of Agriculture (PGIA), University of Peradeniya; and Department of Management of Technology (MOT), University of Moratuwa. These universities had a relatively considerable amount of information on their MBA curriculum online.

Firstly, course objectives and intended outcomes were scanned to identify their role in business design and innovation. Then the course content was skimmed to identify their engagement with creative problem-solving and innovation. Finally, re-read the online available curriculum to locate possible course modules for facilitating with design thinking. In the next section, this paper reviews extant literature relevant to design thinking in global higher education context by selecting scholarly literature primarily on teaching and learning. 


\section{Literature review}

Creativity and innovation have been gaining increasing attention over the last several decades with both practitioners in the industry, and educators promoting the importance of creative thinking for students (Jackson, Oliver, Shaw, \& Wisdom, 2006; Robinson, 2011). Nowadays, examples are found of the development of creative problem solving using various methods. The broader use of design thinking in higher education also started as a way of developing creativity and innovation underpinned by "the conviction that it possible to train [non-designers] to become innovators" (Plattner, Meinel, \& Leifer, 2015, p. V).

Hence the application of design thinking at a broader level in higher education has already been undertaken in a number of contexts. A significant example is The Hasso Plattner Design Thinking Research Program; a collaborative program between Stanford University and the Hasso Plattner Institute $d S c h o o l$ in Potsdam, Germany. The EDUCAUSE (Morris \& Warman, $2015)$ project provides several other examples. In engineering education, the well-known example for design thinking is the ME310 course from 1969 at Stanford University ("ME310 Design Innovation at Stanford University," 2010). According to David Kelly, the roots of design thinking as a humancentred process in higher education goes back to 1960s and its development by John Arnold, Bob (Robert) McKim and Kelly himself in the form of the ME310 and ME101 courses at Stanford (Camacho, 2016).

Design thinking is now being practised, facilitated and taught in disciplines as diverse as design, engineering, business, management, information technology, and education. The list in Table 1 identifies some of the famous universities and graduate schools that are at the forefront of teaching design thinking. Most of the popular design thinking programmes are in transdisciplinary educational contexts which focussed on business, innovation and entrepreneurship: such as Stanford; dSchool; Darden Executive Education programs; and Harvard Business School course, Design Thinking \& Innovation. This popularity is evident in several MOOCs available freely from those universities. Stanford University's Crash Course in Design Thinking; University of Cincinnati's highly popular MOOC on Innovation and Design Thinking; University of Virginia's Design Thinking for Business innovation; and MIT's Design Thinking for Leading and Learning can be considered as examples. The Rotman Business School provides a strong foundation in the traditional functional areas of business: strategy, operations, accounting, finance, marketing, human resources and leadership; as well as business design with design thinking ("Creative Methodology: Rotman School of Management," 2017). Cultivating integrative thinking through MBAs is essential for the future (Moldoveanu \& Martin, 2008). Rotman provides 'Business Design' studios for students for exploration, self-discovery and realworld application. Further, focusing on the question, can executives with superb analytical skills, learn to think more innovatively? and taking the Harvard Business School course as an example while considering business management practices, and entrepreneurial and innovation processes, Datar 
and Bowler (2015) conclude: "individuals trained in design thinking understand the innovation process deeply and so can be more effective in leading innovation" (p. 137).

Table 1. Popular examples of Universities and Graduate Schools Implementing Design Thinking Education*

\begin{tabular}{|c|c|}
\hline USA & \begin{tabular}{l}
\multicolumn{3}{l}{ Stanford University (HPI d.school) } \\
Massachusetts Institute of Technology (System Design \\
Management) \\
Illinois Institute of Technology (Institute of Design) \\
University of Virginia (Darden School of Business)
\end{tabular} \\
\hline Germany & University of Potsdam (HPI d.school) \\
\hline UK & Royal College of Art / Imperial College London \\
\hline Australia & $\begin{array}{l}\text { University of Technology Sydney } \\
\text { Queensland University of Technology } \\
\text { The University of Canberra, RMIT }\end{array}$ \\
\hline Finland & Aalto University (IDBM) \\
\hline Netherlands & $\begin{array}{l}\text { Delft University of Technology } \\
\text { TechnischeUniversiteit Eindhoven }\end{array}$ \\
\hline South Korea & KAIST (DESIGN) \\
\hline China & Zhejian University: Communication University of China \\
\hline Taiwan & XueXue Institute \\
\hline Singapore & $\begin{array}{l}\text { Singapore University of Design and Technology Singapore } \\
\text { Polytechnic } \\
\text { National University of Singapore }\end{array}$ \\
\hline India & $\begin{array}{l}\text { National Institute of Design } \\
\text { Indian Institute of Technology }\end{array}$ \\
\hline Italy & Milan Institute of Technology \\
\hline Denmark & $\begin{array}{l}\text { Technical University of Denmark } \\
\text { Design Skolen Kolding }\end{array}$ \\
\hline France & The École des PontsParisTech (d.thinking) \\
\hline Chile & Pontificia Universidad Catolica de Chile \\
\hline Canada & University of Toronto (Rotman School of Management) \\
\hline Japan & $\begin{array}{l}\text { Kyoto Institute of Technology (Department of Design } \\
\text { Engineering \& Management) } \\
\text { The University of Tokyo (i.school) }\end{array}$ \\
\hline
\end{tabular}

Notes: ${ }^{*}$ Compiled based on several sources including;(Camacho, 2016; Goldman \& Kabayadondo, 2017; Kurokawa, 2013; Matthews \& Wrigley, 2017) 
Today more universities offer design thinking programmes with increasing interest by researchers in the learning outcomes of design thinking programmes. A recent survey suggested that 30 universities out of 43 universities in Australia engaged with design thinking in different levels (Beligatamulla, 2018). Further, there is research to understand the design thinking pedagogy better (Glen, Suciu, Baughn, \& Anson, 2015; Luka, 2014; Wrigley \& Straker, 2017). Although, there is no one best way of teaching innovation and entrepreneurship, student experience and learning outcomes can be significantly improved via integration of a design-driven pedagogy (Huq \& Gilbert, 2017; Willness \& Bruni-Bossio, 2017).

There are several reasons to facilitate design thinking in contemporary education. Lots of research illustrate many characteristics of design thinking: including problem-solving skill, creativity and innovation, which are considered as $21^{\text {st }}$ century's most critical educational outcomes (Beligatamulla, 2016; Goldman \& Kabayadondo, 2017; Koh et al., 2015). Further, Luka (2014) summarises several benefits of facilitating design thinking for students: it is perceived as design-based learning; it is a model for enhancing endurance, engagement; it empowers students to work productively in multi-disciplinary teams and enact positive, design-led change in the world. Design thinking enables iteration and reflection on own actions (Dorst, 2011) while enabling higher order thinking (Luka, 2014; Wrigley \& Straker, 2017).

In general, SL is not much exposed to the broader discussion of design thinking except several business and innovation organisations implementing it in their practice (Daily FT, 2017a, 2017b). There are several instances where the author of this paper has involved in design thinking teaching to a broader community from 2015. However, design thinking is an embedded concept in design (including architecture) education which can be identified in the several courses in the Faculty of Architecture, University of Moratuwa. These are not exposed to the service design, innovation and business management, and to a broader community.

\section{Discussion}

According to the extant scholarly literature review provided above, it is evident that the design thinking is being facilitated in many universities worldwide for business design, entrepreneurship and innovation. In contrast, the scanning of MBA courses in SL established that SL universities are lacking in facilitating design thinking for innovation, although some of the course outcomes mentioned about do foster innovation. The skimming of course contents of the selected MBA programs shows that most of them have a module related to innovation: such as EMBA500-Innovative Entrepreneurship in Executive MBA of the University of Sri Jayewardenepura; EMBA612Innovation and Change Management in Executive MBA of the University of Colombo; MN5212 - Management of Innovation and R \& D in MBA in Management of Technology of the University of Moratuwa; and MBA61213 Innovation and New Product Development in MBA of the University of 
Kelaniya. These course modules may teach participants with some process models for innovation, but those processes are not explicit in the curriculum available online. Re-reading of those MBA curriculums to identify course modules to foster design thinking for innovation suggested that it is possible to facilitate students with design thinking in above-mentioned innovation related modules or studio, and research-and-development based modules.

Some of the curricular from Executive MBAs in SL indicates the notion of supporting innovation in business but how it is being taught and practised is yet a grey area. This may be partly because the curriculums are not that explicit in conveying the full content of the course. However, not only in SL but also in the world, numerous MBA programs have traditionally dedicated on "cultivating analytical skills and specific knowledge (the knowing component in the knowing-doing-being taxonomy), producing excellent analysts and functionaries, but failing to produce enough of the effective leader's businesses need" (Datar \& Bowler, 2015, p. 119). According to the scholarly literature, design thinking has the potential to incorporate doing and being components as well as higher-order-thinking of educational taxonomies.

In one hand, with the current education, "MBA participants are often budding entrepreneurs but rarely inventors" (Ramanantsoa, 2015). On the other hand, design and engineering graduates are often inventing or designing but rarely market their inventive outcomes. Thus, this gap should be bridged and manage the link between innovation and entrepreneurship: the possibility is with the design thinking. However, when facilitating design thinking for entrepreneurship, two key conditions are necessary for learning environments in educational institutions to avoid such teaching being little more than a tool: (1) "the institution needs to promote entrepreneurship very clearly and officially as a key component of its vocation"; and (2) "it must translate this into an operational fact in its rules and procedures" (Ramanantsoa, 2015, p. 182). Although the former condition can be accomplished in many business education programs in Sri Lankan higher education context, it is on the latter that efforts are still mandatory.

According to government development policy frameworks and Asian Development Bank (2016), universities should plan to become centres for economic development, agents of innovation and incubators of entrepreneurship. Some universities including the University of Moratuwa which has the required disciplinary background, that is, design, science, technology and business but in isolation, have started supporting start-ups and spin-off companies(Asian Development Bank, 2016; Larsen et al., 2016). However, design thinking has proven potentials with supporting innovation in start-ups in many counterpart universities such as Stanford and MIT(Camacho, 2016). Thus, learning from the global success universities, design thinking provides a promise to endorse the transdisciplinary nature for business innovation while providing students with a process and mind-set to uncover their creative potentials within Sri Lankan higher education context. 


\section{Conclusion and implications}

This paper started by providing the broader application of design thinking in higher education to enhance student skills. Considering all the facts provided, the value of facilitating design thinking in higher education is evident. However, Sri Lanka has no such engagement with design thinking in higher education. Thus, there is a need to stimulate design thinking for business design and innovation via higher education in Sri Lanka. To do that, transdisciplinary educational settings are needed. As MBA programs from several state universities in Sri Lanka entertain innovation related course outcomes and course stakeholders from different disciplinary backgrounds, it provides a possible platform to accelerate innovation with design thinking.

\section{Acknowledgement}

The foundations for this paper lies on a broader research project on Design Thinking Pedagogy currently conduct at the Queensland University of Technology, Australia. Hence, the author would like to acknowledge all the stakeholders in the major project.

\section{References}

Asian Development Bank. (2016). Innovative strategies in higher education for accelerated human resource development in South Asia: Sri Lanka. Mandaluyong City, Philippines. Retrieved from https://www.adb.org/ sites/default/files/publication/185628/strategies-higher-educationsri.pdf

Beligatamulla, G. (2016). Going human centered: facilitating creative problem solving skills with 'human centered design' (HCD) and 'design thinking' approaches. In Quality Assurance in Higher Education for Effective Learning, Proceedings of the 12th Annual Conference of Higher Education in Sri Lanka (pp. 23-26). Kuliyapitiya: University of Wayamba \& SLAIHEE.

Beligatamulla, G. (2018). Does it matter? Value of reporting both successes and failures of 'design thinking' in higher education. In The Twelfth International Conference on Design Principles \& Practices (p. Virtual Lightning Talk). Barcelona: Common Ground Research Networks.

Boland, R., \& Collopy, F. (Eds.). (2004). Managing as designing. Stanford: Stanford University Press.

Brown, T. (2009). Change by design: how design thinking transforms organizations and inspires innovation. New York: Harper Collins.

Camacho, M. (2016). In Conversation David Kelley: From design to design thinking at Stanford and IDE0. She Ji: The Journal of Design, Economics, and Innovation, 2(1), 88-101. https://doi.org/10.1016/j.sheji. 2016.01.009

Rotman School of Management. (2017). Creative methodology. Retrieved March 22, 2018, from http://www.rotman.utoronto.ca/Degrees/ MastersPrograms/MBAPrograms/FullTimeMBA/Program/CreativeMet hodology 
Cross, N. (2006). Designerly ways of knowing. London: Springer.

Daily FT. (2017a). Design and why it matters for manufacturing: Wijeya Newspapers Limited company profile. Retrieved April 16, 2018, from Factiva database

Daily FT. (2017b). Sri Lanka must up-skill talent across all identified sectors: Wijeya Newspapers Limited company profile. Retrieved April 16, 2018, from Factiva database

Datar, S., \& Bowler, C. N. (2015). Design Thinking and innovative problem solving. In J. Canals (Ed.), Shaping Entrepreneurial Mindsets: Innovation and Entrepreneurship in Leadership Development (pp. 119-138). Palgrave Macmillan Limited.

Dorst, K. (2011). The core of "design thinking" and its application. Design Studies, 32(6), 521-532. https://doi.org/10.1016/j.destud.2011.07.006

Dutta, S. (Ed.). (2012). The Global Innovation Index 2012: stronger innovation linkages for global growth. Fontainebleau: INSEAD and WIPO. Retrieved from www.globalinnovationindex.org

Dym, C. L., Agogino, A. M., Eris, O., Frey, D. D., \& Leifer, L. J. (2005). Engineering design thinking, teaching, and learning. Journal of Engineering Education, 94(January), 103-120. https://doi.org/10.1109/EMR.2006. 1679078.

Frisendal, T. (2012). Design Thinking Business Analysis: Business Concept Mapping Applied. New York Dordrecht London: Springer Heidelberg. https://doi.org/10.1007/978-3-642-32844-2.

Glen, R., Suciu, C., Baughn, C. C., \& Anson, R. (2015). Teaching design thinking in business schools. The International Journal of Management Education, 13, 182-192. https://doi.org/10.1016/j.ijme.2015.05.001

Goldman, S., \& Kabayadondo, Z. (Eds.). (2017). Taking design thinking to school: how the technology of design can transform teachers, learners, and classrooms. New York and London: Taylor and Francis.

Holloway, M. (2009). How tangible is your strategy? How design thinking can turn your strategy into reality. Journal of Business Strategy Strategy, 30(2), 50-56. https://doi.org/10.1108/02756660910942463.

Huq, A., \& Gilbert, D. (2017). All the world's a stage: transforming entrepreneurship education through design thinking. Education + Training, 59(2), 155-170. https://doi.org/10.1108/ET-12-2015-0111

Jackson, N., Oliver, M., Shaw, M., \& Wisdom, J. (Eds.). (2006). Developing creativity in higher education: the imaginative curriculum. London: Routledge.

Johansson-Sköldberg, U., Woodilla, J., \& Çetinkaya, M. (2013). Design thinking: Past, present and possible futures. Creativity and Innovation Management, 22(2), 121-146. https://doi.org/10.1111/caim.12023

Kimbell, L. (2011). Rethinking design thinking: Part I. Design and Culture, 3(3), 285-306. http://dx.doi.org/10.2752/175470811X13071166525216

Koh, J. H. L., Chai, C. S., Wong, B., \& Hong, H.-Y. (2015). Design thinking for education: conceptions and applications in teaching and learning. Singapore: Springer.

Kurokawa, T. (2013). Design Thinking education at universities and graduate schools. Science and Technology Trends: Quarterly Review, 46(February), 
$50-63$.

Larsen, K., Bandara, D. C., Esham, M., \& Unantenne, R. (2016). Promoting university-industry collaboration in Sri Lanka: status, case studies, and policy options. Washington, DC: Washington, DC: World Bank Group.

Lawson, B. (2006). How designers think: the design process demystified (4th ed.). Oxford: Architectural Press, Routledge.

Liedtka, J., Salzman, R., \& Azer, D. (2017a). Democratizing innovation in organizations: teaching design thinking to non-designers. Design Management Review, 28(3), 49-55. https://doi.org/10.1111/DREV. 12090

Liedtka, J., Salzman, R., \& Azer, D. (2017b). Design thinking for the greater good: Innovation in the social sector. New York: Columbia University Press.

Luka, I. (2014). Design Thinking in pedagogy. Journal of Education Culture and Society, 2, 63-74. https://doi.org/10.15503/jecs20142.63.74

Matthews, J., \& Wrigley, C. (2017). Design and design thinking in business and management higher education. Journal of Learning Design, 10(1-Special Issue: Business Management), 41-54.

ME310 Design Innovation at Stanford University. (2010). Retrieved January 4, 2018, from https://web.stanford.edu/group/me310/me310_2016/ about.html

Moldoveanu, M. C., \& Martin, R. L. (2008). The future of the MBA: designing the thinker of the future. Oxford New York: Oxford University Press.

Morris, H. E., \& Warman, G. (2015). Using design thinking in higher education. Retrieved August 3, 2016, from http://er.educause.edu/articles /2015/1/using-design-thinking-in-higher-education

Muratovski, G. (2016). Paradigm shift: report on the new role of design in business and society. She Ji: The Journal of Design, Economics, and Innovation, 1(January). https://doi.org/10.1016/j.sheji.2015.11.002

Plattner, H., Meinel, C., \& Leifer, L. (2015). Design thinking research: making design thinking foundational. Design Thinking Research: Making Design Thinking Foundational. https://doi.org/10.1007/978-3-319-19641-1

Ramanantsoa, B. (2015). Entrepreneurship and innovation: business schools as drivers of change. In Shaping Entrepreneurial Mindsets: Innovation and Entrepreneurship in Leadership Development (pp. 175-188). New York: Canals, Jordi.

Robinson, K. (2011). Out of our minds: learning to be creative (Revised and updated ed.). West Sussex: Capstone Publishing Ltd (a Wiley company).

Vianna, M., Vianna, Y., Adler, I. K., Lucena, B., \& Russo, B. (2012). Design Thinking: Business Innovation (1 ${ }^{\text {st }}$ eletro). Rio de Janeiro: MJV Press.

Willness, C., \& Bruni-Bossio, V. (2017). The curriculum innovation canvas: a design thinking framework for the engaged educational. Journal of Higher Education Outreach \& Engagement, 21(1), 134-164.

Wrigley, C., \& Straker, K. (2017). Design thinking pedagogy: the educational design ladder. IInnovations in Education and Teaching International, 54(4), 374-385. https://doi.org/10.1080/14703297.2015.1108214. 